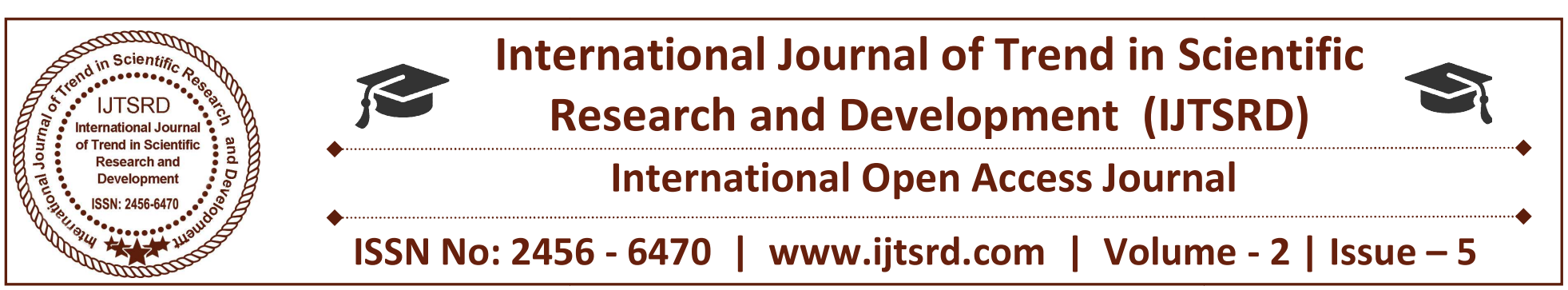

\title{
Impact of Electronic Banking on Customer Satisfaction
}

\author{
Urvashi Solanki \\ B.A., L.L.B. (Hons), Indore Institute of Law, \\ Indore, Madhya Pradesh, India
}

\section{ABSTRACT}

In the Rapid development of our country. It is the most leading part of the financial sector of the country as it is responsible for more than $70 \%$ of the funds flowing through the financial sector in the country. The banking system in the country has three primary functions:

$>$ Operations of Payment system

$>$ Depositor and protector of people's savings

$>$ Issue loans to individual and Companies

Introduction of technology in banking sector has enabled customers to avail the banking services at anytime and anywhere in the form of ATM, Mobile banking, \& Internet Banking. Banks today operate in a highly globalized, liberalized, privatized and a competitive environment. In order to survive in this environment banks have to use IT. Indian banking industry has witnessed a tremendous developments due to sweeping changes that are taking place in the information technology. Electronic banking has emerged from such an innovative development. The objective of the present paper is to study and analyse the progress made by Indian banking industry in adoption of technology. The study is secondary based and analytical in nature. The progress in e banking in Indian banking industry is measured through various parameters such as Computerization of branches, Automated Teller Machines, Transactions through Retail Electronic Payment Methods etc. Statistical and mathematical tools such as simple growth rate, percentages and averages etc are used. The paper also highlights the challenges faced by Indian banks in adoption of technology and recommendations are made to tackle these challenges. The paper concludes that in years to come e-banking will not only be acceptable mode of banking but preferred mode of banking.

\section{INTRODUCTION}

Banking system plays an important role in every country economy. It is important for any nation as it provide need of credits for all the sector of the society. India is not only the world largest democracy but it is also emerging economic giant ${ }^{1}$ The growth of a country depends on its banking. Banking in our country is gone through a long journey. There are several of change in banking due to technology and innovation.

Technology has become the part of our life in almost all sector and even in banking. The use of technology have so increased in across all areas of banking business. E-banking have an immense growth in India since past years. Anywhere and anytime banking has became reality. E-banking is the most easiest way of banking. E-banking is considered to have a substantial impact on bank performance. The success of this is that it can provide numerous benefits to banks as well as to customers. E- banking is growing because more and more people are adopting this system of banking. In simple words E-banking means any user with a personal computer and a browser can get connected to his bank's website to perform any of the banking function. Or accessing banking function through internet is also e-banking.

E-banking provides no. of benefits to customers in terms of ease and cost of transactions, either through Internet, telephone or other electronic delivery.

\section{Electronic Banking And its Evolution}

In the modern times, banking occupies an important place in the financial part of every economy. The word „bank ${ }^{\text {ee }}$ is used in the sense of a commercial

\footnotetext{
${ }^{1}$ http://euroasiapub.org
} 
bank. It"s of Germanic origin though some persons trace its origin to the French word „Banquiee and the Italian word „Banca ${ }^{e e}$. It referred to a bench for keeping, lending, and exchanging of money or coins in the marketplace by moneylenders and money changers (Krishna and Gopal, 2008).

Banking in India originated in the last decades of the 18th century. The first bank was The General Bank of India which started in 1786, and followed by the establishment of the Bank of Hindustan, both of which are now defunct. The oldest bank in existence in India is the State Bank of India, which originated with the name of the Bank of Calcutta in June 1806, which almost immediately became the Bank of Bengal. This was one of the three presidency banks, the other two being the Bank of Bombay and the Bank of Madras. All three were established under charters from the British East India Company (Mumtaz, 2009). The business of these presidency banks were initially confined to discounting of bills or other negotiable private securities, keeping cash accounts, receiving deposits, and issuing and circulating notes (Bhasin, 2006). The three banks merged in 1921 to form the Imperial Bank of India which became the State Bank of India after independence. Indian merchants in Calcutta established the Union Bank in 1839, but it failed in 1848 as a consequence of the economic crisis of 1848-49. The Allahabad Bank, established in 1865 and still functioning today, is the oldest Joint Stock bank in India (Joint Stock Bank: A company that issues stock and requires shareholders to be held liable for the company's debt). It was not the first though. That honor belongs to the Bank of Upper India, which was established in 1863, and which survived until 1913, when it failed, with some of its assets and liabilities being transferred to the Alliance Bank of Simla. Foreign banks too started to arrive, particularly in Calcutta, in 1860s. The Comptoire d'Escompte de Paris opened a branch in Calcutta in 1860, and another in Bombay in 1862 followed by branches in Madras and Puducherry, then a French colony. HSBC established itself in Bengal in 1869. Calcutta was the most active trading port in India, mainly due to the trade with the British Empire, and so became a banking center. The first entirely Indian joint stock bank was the Oudh Commercial Bank, established in 1881 in Faizabad. It failed in 1958. The next was the Punjab National Bank, established in Lahore in 1895 which has survived to the present and is now one of the largest banks in India. The period between 1906 and 1911, saw the establishment of banks inspired by the Swadeshi movement. The Swadeshi movement inspired local businessmen and political figures to found banks of and for the Indian community. A number of banks established then have survived to the present such as Bank of India, Corporation Bank, Indian Bank, Bank of Baroda, Canara Bank and Central Bank of India. The fervour of Swadeshi movement lead to establishing of many private banks in Dakshina Kannada and Udupi district which were unified earlier and known by the name South Canara ( South Kanara ) district (Mumtaz, 2009).

In spite of all these developments, independent India inherited a rather weak banking and financial system marked by a multitude of small and unstable private banks whose failures frequently robbed their middleclass depositors of their life ${ }^{\text {ee }}$ savings. After independence, the Reserve Bank of India was nationalized in 1949 and given wide powers in the area of bank supervision through the Banking Companies Act (later renamed Banking Regulations Act). The nationalization of the Imperial Bank through the formation of the State Bank of India and the subsequent acquisition of the state owned banks in eight princely states by the State Bank of India in 1959 made the government the dominant player in the banking industry. In keeping with the increasingly socialistic leanings of the Indian Government, 14 major private banks, each with deposits exceeding Rs. 50 crores, were nationalized in 1969. This raised the proportion of scheduled bank branches in government control from $31 \%$ to about $84 \%$. In 1980 , six more private banks each with deposits exceeding Rs 200 crores were nationalized further raising the proportion of government controlled bank branches to about $90 \%$. As in other areas of economic policy-making, the emphasis on government control began to weaken and even reverse in the mid-1980s and liberalization set in firmly in the early 1990s (Chakrabarti, 2005).

\section{RESULT AND DISCUSSION}

\section{Tools of electronic banking}

\section{Automated Teller Machine (ATM)}

An ATM is a computerized Tele-communication device which provides the customers the access to financial transactions in public places without human inter-mention. It enables the customers to perform several banking operations such as withdrawals of cash, request of mini-statement etc. 
2. Electronic Transfer of Funds

This is an electronic debit or credit of customers account. Bank customers can buy goods and services without caring cash by using credit or debit cards. There cards are issued to the customers by the bankers. This system works on a pin (personal identification number).

The Customer swipes the card by using the card reader device to make the transactions. The development of electronic banking and internet banking helped the customers to utilize their services.

\section{Tele-Banking}

It is increasingly used in these days. It is a delivery channel for marketing, banking services. A customer can do non-cash business related banking over the phone anywhere and at any time. Automatic voice recorders are used for rendering tale-banking services.

\section{Mobile Banking}

It is another important service provided by the banks recently. The customers can utilize it with the help of a cell phone. The bank will install particular software and provide a password to enable a customer to utilize this service.

\section{Home Banking}

It is another important innovation took place in Indian banking sector. The customers can perform a no. of transactions from their home or office. They can check the balance and transfer the funds with the help of a telephone. But it is not that popularly utilized in our country.

\section{Internet Banking}

It is the recent trend in the Indian banking sector. It is the result of development took place in information technology. Internet banking means any user or customer with personal computer and browser can get connected to his banks website and perform any service possible through electronic delivery channel. There is no human operator present in the remote location to respond. All the services listed in the menu of bank website will be available.

\section{Credit Cards}

A credit card is a small plastic card issued to users as a system of payment. It allows its holder to buy goods and services based on the holder's promise to pay for these goods and services. The issuer of the card creates a revolving account and grants a line of credit to the consumer (or the user) from which the user can borrow money for payment to a merchant or as a cash advance to the user. A credit card is different from a charge card: a charge card requires the balance to be paid in full each month. In contrast, credit cards allow the consumers a continuing balance of debt, subject to interest being charged. A credit card also differs from a cash card, which can be used like currency by the owner of the card. Most credit cards are issued by banks or credit unions.

\section{Debit Card}

A debit card (also known as a bank card or check card) is a plastic card that provides the cardholder electronic access to his or her bank account/s at a financial institution. Some cards have a stored value against which a payment is made, while most relay a message to the cardholder's bank to withdraw funds from a designated account in favour of the payee's designated bank account. The card can be used as an alternative payment method to cash when making purchases. In some cases, the cards are designed exclusively for use on the Internet, and so there is no physical card. In many countries the use of debit cards has become so widespread that their volume of use has overtaken or entirely replaced the check and, in some instances, cash transactions. Like credit cards, debit cards are used widely for telephone and Internet purchases. However, unlike credit cards, the funds paid using a debit card are transferred immediately from the bearer's bank account, instead of having the bearer pay back the money at a later date.

\section{Advantages of $\mathrm{E}$ banking}

\section{Save time and money}

You can save both time and money by dealing with your day-to-day banking business using Danske e Banking. Time, because you do not have to stand in line at the bank; and money, because e Banking is free of charge if you already have one of our customer packages.

2. Get an overview of your financial situation E banking gives you an overview of your transactions. You can always check your balance, and you can prepare and handle more long-term budgets.

3. No more paper bills and piles of paper Tired of receiving bills in the mail? Get your bills directly via e Banking. You will get a better overview of your financial situation and help reduce paper consumption. 


\section{Number of $\mathbf{E}$ banking users in India}

With the ongoing digital drive in India, the number of users opting for online banking is expected to double to reach 150 million mark by 2020 , from the current 45 million active urban online banking users in India

With the ongoing digital drive in India, the number of users opting for online banking is expected to double to reach 150 million mark by 2020, from the current 45 million active urban online banking users in India, according to a report drafted by Facebook and The Boston Consulting Group (BCG). In a report, titled "ENCASHING ON DIGITAL: Financial Services in 2020", the two firms have highlighted the rising influence of digital in financial services and the transformation required to make the most of this revolution. "India could not be more ready for a digital revolution in financial services - with government interventions on one hand and growing consumer awareness on the other. Wide scale adoption of digital has the potential of reducing cost of acquisition and cost of servicing to $1 / 10$ th. This can substantially improve customer level profitability and can add to retail profit pool by $\$ 3-3.5$ billion by 2020," said Amit Kumar, Partner and Managing Director, The Boston Consulting Group, India.

India is in the midst of a digital revolution, with Internet users going beyond just search and social networking and moving to more mature activities like online shopping and banking. Already 70 percent urban internet users are digitally influenced during financial product purchase, that is, they use at least one digital channel during the purchase journey of a financial product. In terms of digital adoption, financial services is already much larger than other categories like consumer electronics or travel.
"As more and more Indians access the internet on their mobile phones, there is a big opportunity for financial companies to create a powerful digital experience that is intuitive and secure for their customers. The report confirms that consumers are leaning in towards digital adoption of financial services faster than previous estimates, and the time is now for the financial services industry to invest so we can help more people contribute to a digital future." said Umang Bedi, Managing Director, Facebook India and South Asia.

According to the report, along with the new Indian consumer, the digital ecosystem of India has also evolved rapidly over the last few years. India is set to leapfrog many advanced economies in this space. From creating 'Digital India', to setting up open architecture layers such as Aadhar, India Stack, Bharat Bill Payment System and GST, the Indian government is actively developing the entire digital ecosystem. The report highlights that in spite of a growing digital adoption by the consumer and increased government focus on digital infrastructure, financial institutions are yet to fully harness the opportunity.

More than 50 percent of consumers are dissatisfied with tnking and mobile app experience largely because of fear of hidden charges, lack of trust, complicated information provided among others. This is also indicated by the very low downloads of mobile apps of financial institutions when compared with ecommerce apps. 


\section{Customer Satisfaction from E banking}

\section{Q.6) TO WHAT EXTENT IS YOU SATISFIED WTTH YOUR BANKS' E-BANKING} SERVICES?

\begin{tabular}{|l|l|}
\hline LEVEL OF SATISFACTION & NO. OF RESPONDENTS \\
\hline Highly Satisfied & 38 \\
\hline Satisfied & 58 \\
\hline Neutral & 32 \\
\hline Dissatisfied & 5 \\
\hline TOTAL & 133 \\
\hline
\end{tabular}

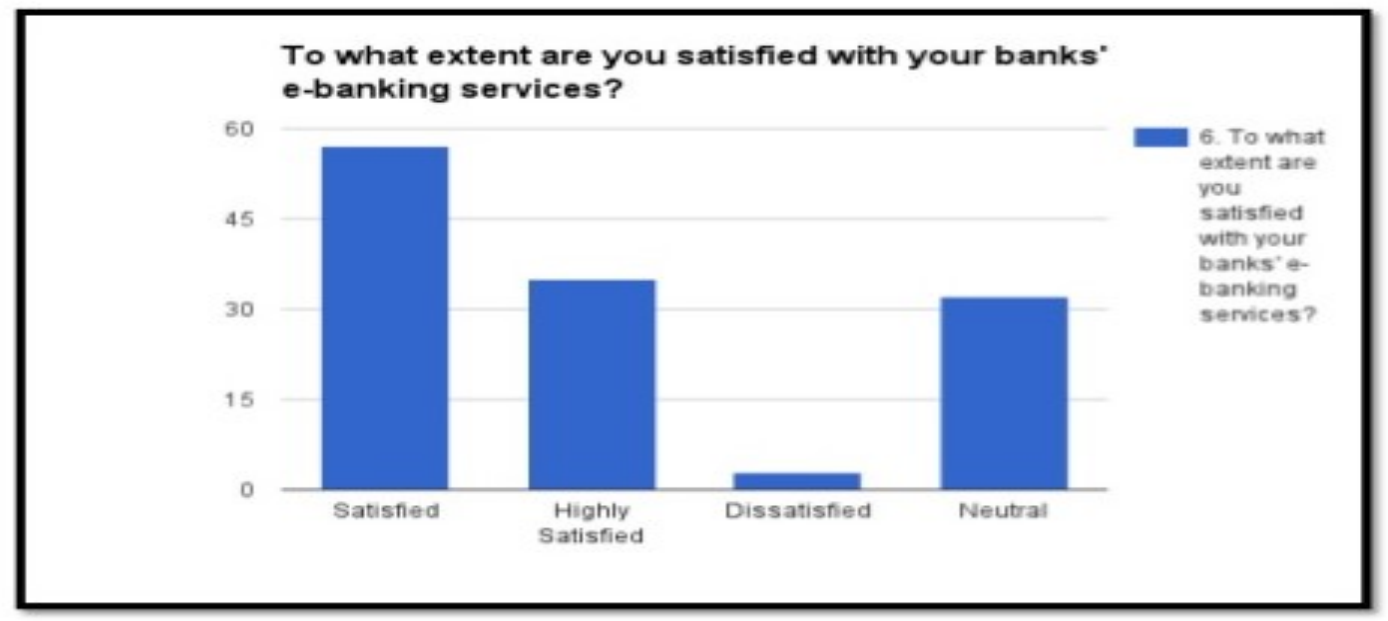

Interpretation: From the above chart it represents that $43 \%$ of people are satisfied, while $28.5 \%$ of people are highly satisfied and $24 \%$ of them are neutral and the rest are dissatisfied with their e-banking services. Which in overall we can say that there is a high rate of satisfaction level from the e-banking services.

\section{CONCLUSION}

In India, E-banking is in a nascent stage. No doubt Indian banks are making sincere efforts for the adoption of advanced technology and installation of edelivery channels but still masses are vary of the concept. Banks are making sincere efforts to popularize the e-banking services and products. Younger generation is beginning to see the convenience and benefits if e-banking. In years to come, e-banking will not only be acceptable mode of banking but will be preferred mode of banking.

\section{REFERENCES}

www.icommercecentral.com

www.ijtra140137.pdf

ANI/New Delhi

http://europasoapub.org 